\title{
Construction of the Employment-Oriented and Modular English Teaching System in Higher Vocational Colleges
}

\author{
Li Gong \\ Jiangxi Technical College of Manufacturing, 330095, China
}

Keywords: Higher vocational colleges, English teaching; module, Employment orientation.

\begin{abstract}
Now, higher vocational English teaching has gradually won more and more attention. However, there are still some problems with students' learning initiative, teaching practicability, employment orientation and so on. Therefore, it is quite essential to construct an employment-oriented and modular English teaching system in higher vocational colleges. This paper firstly analyzes current higher vocational English teaching status and existing problems, then explores the significance to construct an employment-oriented and modular English teaching system in higher vocational colleges, and lastly proposes several targeted strategies for the system construction.
\end{abstract}

\section{Introduction}

In Requirements for Higher Vocational English Curriculum Teaching, it defines that: higher vocational English teaching must target students' practical application ability as well as practicability and pertinence of teaching. However, common existing problems like deficient practical application in higher vocational English teaching seriously restrict the cultivation of students' English quality and improvement of their employability. In terms of higher vocational English teaching localization and students' present employment situation, it is necessary to construct an employment-oriented and modular teaching system.

\section{Analysis on the Current Status of Higher Vocational English Teaching}

In China, higher vocational colleges gradually pay more attention to English teaching and consistently implement reforms and optimization. While at present stage, there are still many problems. Firstly, although many higher vocational colleges set up professional English courses, due to the absence of enough attention, these are just considered as auxiliary courses. In addition, unreasonable class arrangement results in students' learning difficulty, poor learning effect and gradual reduction of learning interests. Besides, in a lot of higher vocational colleges, English teaching focuses on specialized vocabulary, professional basic knowledge, writing and reading, but neglects the practice of listening and speaking. This kind of teaching method fails to inspect students' grasp of English basic knowledge, nor lead them to keep up with cutting-edge trends in their professional fields. Secondly, there is no room for students to play their subjectivity. The indoctrination teaching mode, relying on teachers and teaching materials, puts students in a negative position to receive knowledge and deprives their language practice chances. Thirdly, there are problems in English teaching like low practicability and deficient service for students' majors. During teaching process, more importance is attached to English basic knowledge than the cultivation of practical application ability. Curriculum contents, teaching design implementation and curriculum evaluation are copied blindly from the English teaching mode of undergraduate colleges, which deviate from the talent cultivation direction of professional education and result in many graduates' low professional English level and incompetence to meet current market demands for talents. Moreover, from the teaching evaluation point of view, many higher vocational colleges take final exam results (mostly written examinations) to assess students' English learning effect. ${ }^{[1]}$ However, as a language subject, English written examinations fail to give a comprehensive 
assessment of students' language ability, inspect their English professional application ability or activate learning initiative. How to construct a reasonable employment-oriented teaching evaluation system is a vital question for higher vocational colleges to consider.

\section{Importance of the Construction of Modular Higher Vocational English Teaching System}

Higher vocational colleges target the cultivation of high-quality and skilled talents. In the era of economic globalization, with increasing international communicative cooperation and more foreign-funded enterprises, English has become indispensable for students' employment and career development, which puts forward more demands to higher vocational graduates. For those students, except for strong professional skills, they also need to learn and master professional English. So English teaching should serve the core objective of employment, providing professional knowledge and skills needed in students' future employment. The cultivation goals of employment-oriented higher vocational English teaching determine that, in English curriculum, it is not feasible to indoctrinate language knowledge. The curriculum structure must be profession-oriented and employment-oriented. Thus, it is extremely vital to build an employment-oriented English teaching mode which takes professional courses for reference and serve students' future employment. Modular teaching system can effectively meet these requirements.

Modular teaching divides teaching contents into several modules. In term of its meaning, firstly, through modular English teaching method, teaching will be in an organic combination with employment. Curriculum system can be set flexibly according to employment needs of higher vocational students, which will break the traditional English subject system and curriculum strategies, as well as update teaching framework and teaching contents. The modular teaching system and staged curriculum arrangement display the essence of higher vocational English teaching and create more free and broad space for learning, letting students study with purposes according to their own English basis, interests and preference for employment and improving their English skills. ${ }^{[2]}$

Secondly, modular teaching is advantageous in practicality, flexibility etc., which can fully take students as the center and reflect their subjectivity in class according to their diversity. Obviously, the traditional teacher-centered English teaching mode is no longer suited to the current students' needs, while modular teaching advocates students' active participation, regards them as the learning subject and consider teachers just as guides. So, by this modular teaching mode, we are able to construct a student-centered teaching system, leading students to learn English knowledge deeply and actively, to participate in related activities and to turn them to be "I want to learn" from "want me to learn". In this way, the internal driving force is enhanced and learning efficiency is increased.

In addition, modular curriculum system fully combines English teaching with students' professional learning and on-the-job training. The curriculum objectives base on students' job requirements and vocational settings, curriculum contents follow the development of professional skills and curriculum system targets students' professional ability as well as employment. Those practical modules will effectively promote higher vocational English teaching development, reinforce students' competitive power in employment, expand their employment channels and lay a solid foundation for their career development.

\section{Strategies for the Construction of Modular English Teaching System in Higher Vocational Colleges}

Based on the current status of higher vocational English teaching and characteristics of modular teaching system, an employment-oriented and modular English teaching system will be constructed.

Higher vocational English teaching should target students' practical ability, base on employment orientation, and define teaching goals of modular curriculum system. Teaching can be divided into three modules. First is the Basic English Module. Here, main courses are Comprehensive English, Oral English, Listening and so on. The teaching goals are improving students' vocabulary, grammar etc., in order to lay a solid foundation for the following skills training. Second is the Industry 
English Module. It contains general English related to students' majors which plays an important role during the transition from basic English to professional English, communicative skills in workplace, job hunting, enterprise culture and career development planning etc. The Industry Module plays the core role of the whole modular teaching system and aims to fuse English learning with employment. The third is Professional English Module. ${ }^{[3]}$ Its essence is to cultivate students' professional English knowledge and skills, as well as to enhance their English practical application ability in positions. This module focuses on professional skills training and employability cultivation.

There are enormous majors in higher vocational colleges while English teaching in different majors are diverse. Therefore, it is essential to define the contents of English teaching modules. Under the guidance of modular teaching and basing on employment orientation, teachers can select and supplement contents that are related to students' professional needs. First, the contents of Basic teaching Module such as listening, oral English, reading, written translation, writing, etc., must be mastered by students of all majors. Teachers can divide them into several smaller modules and different majors select appropriate modules to learn in combination with their own professional needs. For example, students of Foreign Trade major can put their focus on translation and writing modules. For students of Foreign- related Tourism major, listening and speaking modules are necessary to be regarded as compulsory. Industry English Module needs to confirm contents that are related to majors by following the principles of sufficiency and practicability. Contents like listening, speaking, reading and writing of technical terms, English expression of professional basic theories and basic principles, translation of professional English knowledge, professional English literature reading and so on. In Professional English Module, practical training is given first priority and students will achieve practice in vocational settings. Moreover, according to different English needs of different majors and diverse English teaching goals, higher vocational colleges are supposed to do teaching materials research and compile modular teaching materials which will be favor of students' professional skills cultivation. ${ }^{[4]}$ For instance, in order to cultivate students' professional English skills, it is feasible to draw up "Employment English”, covering contents like job hunting, communicative skills in workplace, enterprise culture and so on.

In Basic English Teaching Module, teachers are supposed to fully respect students' subjectivity and apply flexibly teaching methods such as case-based teaching, project-based teaching, simulation teaching and so on. This module stresses student-centered and positive arrangement of teaching activities and training of students' communicative ability as well as reading competence in activities, such as English debate competitions, English lectures etc. Through a variety of teaching methods, students' English learning interests will be enhanced and their Basic English qualities such as oral expressions will be improved. In Industry English Module, teachers should pay attention to the connection between basic knowledge and practice. Students are required to complete certain learning tasks by themselves. For instance, for students of Law major, it is suggested to do court simulation, which will let them to learn English knowledge related to Law major through classroom situational performance, and assign after-school tasks in order to make them refer to materials related to legal terms. Through this kind of teaching method, it will not only cultivate students' oral expression and logical ability, but also improve effectively their major understanding and practical English application ability. ${ }^{[5]}$ Professional English Module lays emphasis on the effective combination of English teaching with internship and aims to realize professionalization of English curriculum. Its teaching methods are position-oriented which make students learn English knowledge in professional environment and experience the real functions of English learning. For example, for students majored in Business English, the Professional English Module must contain skills training, base training and on-the-job training. In skills training, it is necessary to define practical goals in combination with major courses like Foreign Trade Correspondence, International Trade Practice and so on. Base training and s on-the-job training are considered to enhance the cooperation between higher vocational colleges and enterprises and offer real foreign trade internship to students.

Examination and evaluation are also important parts of modular English teaching in higher 
vocational colleges, so a systematic and complete evaluation system for students should be constructed by taking the characteristics of modular teaching into consideration. Firstly, for Basic English Module, it is suggested to arrange unified examinations to assess students' English basis and basic qualities. For Industry English Module, it is supposed to pay attention to students' grasp of professional English knowledge by taking their majors into consideration. In Professional English Module, it is viable to arrange society, enterprises and employers to take part in the teaching evaluation. The evaluation of each module should include formative evaluation, in which, students' daily learning attitude, attendance, classroom performance, practice participation etc. will be counted as their usual performance grade in accordance with corresponding scores. ${ }^{[6]}$ Students' comprehensive evaluation grades are calculated in accordance with the comprehensive evaluation grades of each module and a certain proportion. Overall, it is suggested to change the traditional closed and simple teaching evaluation by constructing a modular evaluation system. In this way, students' assessment and evaluation are more in line with the characteristics of professional education and meet the needs of employment orientation.

\section{Conclusion}

In a word, with the changing employment needs of society, confronting with new environments and new needs of higher vocational colleges, higher vocational English should seize the opportunity, face the challenge, reform and renew the traditional teaching mode, construct an employment-oriented and modular English teaching system, as well as enhance students' learning subjectivity in term of their practical needs of English learning. Moreover, higher vocational English teaching need to target the cultivation of students' practical ability and career development, highlight the characteristics of professional education, give a full play to higher vocational English teaching, promote students' competitiveness in job hunting and foster more high quality and skilled application talents for the society.

\section{References}

[1]Ma Lei. A study of the service-oriented and employment-oriented higher vocational English teaching-take Xinjiang Institute of Light Industry Technology as an example [J]. Science and Technology, 2015(9):167-168.

[2]Liu Dong. A study of the modular Basic English teaching in higher vocational colleges [J]. Journal of Jiamusi Vocational Institute, 2013(8): 356.

[3]Wang Hongxia. An exploration on the reform of employment-oriented higher vocational English teaching - take Foreign Trade major as an example [J]. Journal of Kaifeng Institute of Education, 2015(6): 132-133.

[4]Wang Ruihua. A discussion of the application of diversified evaluation systems in modular oral English teaching in higher vocational colleges [J]. Journal of Chang Chun Education Institute, 2015(18): 145-147.

[5]Zhang Jie. A discussion of the modular English teaching in higher vocational colleges based on the perspective of professional ability [J]. Intelligence, 2014(21): 190-191.

[6]Zhang Ning. A practice and exploration of the "menu type" modular English teaching in higher vocational colleges [J]. Journal of Ningbo Polytechnic, 2015(2): 40-43. 